\title{
Property Value, Urban Quality and Maintenance Condition: A Hedonic Analysis in the City of Naples, Italy
}

\author{
Vincenzo Del Giudice ${ }^{1, a}$, Francesca Torrieri ${ }^{1, b}$, and Pierfrancesco De Paola ${ }^{3, c}$ \\ ${ }^{1}$ Department of Industrial Engeneering, University of Naples Federico II, Italy \\ a ingdelgiudice@libero.it, ${ }^{b}$ frtorrie@unina.it, ' pfdepaola@libero.it
}

Keywords: Semiparametric Additive Model, Maintenance Condition, Urban Quality, Real Estate Value.

\begin{abstract}
The article examines the relationship between property value and level of conservation of public urban space. While many studies have examined the effect of "proximity" of open space, parks, and trees on property value, there has been few examination of how projects of urban revitalization and ordinary and extraordinary maintenances of public spaces can influence property values. While intuition can suggest that a low level of quality and maintenance of a public space can negatively affect property value, even if the standard requirement of public spaces and services are meet, this yet to be empirically proven.

We proposes the application of a new econometric models for quantitative analysis of the characteristics of real estate property (Generalized Additive Model), to assess the impact of maintenance condition on property values, due to the better prevision that these functions can obtain in a real estate market context.

The control of the formal and logical adequacy of the proposed theoretical model is referred to the case study under analysis, in the city of Naples. The results obtained show that a "well preserved" urban environment influences property price by approximately $6 \%$. The experimental test of the model has provided results that, by reason of their formal consistency with the results obtained in other contexts, can be considered representative of the effectiveness of the methodology proposed.
\end{abstract}

\section{Introduction}

As is known, many internal and external factors affect the property value, i.e. housing characteristics (e.g. number of rooms and quality of accommodation), neighborhood characteristics (e.g. level and quality of social infrastructure, housing density, and presence of other facilities) and the quality of the environment (air pollution, noise level, etc.).

Looking at the external factors, many studies measure the impact that the "presence" or "proximity" of urban standard and infrastructures (i.e. accessibility), have on property value, whereas a few address the issue of how urban maintenance condition and in general "urban quality," can influence property values.

The concept of "urban quality" is really a complex one and has taken on different meanings over time and across different contexts [1]. The current debate, in the scientific community and political arena is extremely various and multidisciplinary. The attention is focused on the concept of complexity and integration of functions, looking at urban space as a "system" where environmental, historical and social values coexist [2,3,4], associated with a concept of sustainability [5].

Martincigh, defines "urban quality" as the capacity that the urban environment configuration has to meet in quantitative and qualitative terms the overall needs of users by offering tangible and intangible performance required [6].

Many "proxy" variables have been investigated to measure the impact of "urban quality" on property value. A complete analysis of the international literature on how site quality influence housing value is reported in D'Acci 2014 [7].

Several studies measure the distance to different types of nearby green space and find that property value increases with "proximity" and that the effect varies by type $[8,9,10,11]$. 
Other recent studies measure the total "quantity" of surrounding open space [12] the impact of a "pleasant view" $[12,13]$ the presence of public transport and accessibility, the proximity to school $[14,15]$ and the level of traffic, noise and pollution $[16,17,18,19]$.

The studies of Damigos \& Anyfantis [13] appear significant, for the purposes of our analysis, which investigate the effect that the presence of degraded open spaces or non-reclaimed waste in an urban environment may have on property values.

The results obtained show that the lack of maintenance of open spaces and therefore the consequent degradation are reflected in a decrease in the capital property value of approximately $6 \%$.

In an Italian context, D'Acci [20,21, 22], estimates that as a result of urban regeneration projects the increase in property values, ranges from $8 \%$ to $63 \%$.

Del Giudice, De Paola, Torrieri [23], estimate, in a context of a suburb of the city of Naples, that the loss of quality of urban design, increases property value for a rate of about $2.7 \%$.

In our case we want to investigate whether the urban context conservation status, in reference to its public spaces, green areas and the road conditions, can influence property values; or, if the lack of maintenance, and therefore, the "degradation" that often connotes public spaces, can be result in a decrease of real estate values.

The methodology used to assess the impact of urban quality on property price is, in the majority of cases, the hedonic price method [24] based on the analysis of real estate prices.

The results obtained, although in very different contexts, show that, there is a positive effect of "proximity" to open spaces and green areas for residential buildings, especially those located in densely populated urban areas where public spaces if "well preserved" are considered meeting areas and places for leisure time of the citizens.

However, it seems appropriate to measure in economic terms the benefits that society receives from living in an urban environment where a good level of "urban quality" is guaranteed, against the costs that the government must support in order to provide the required performance.

This is especially true at a time of shortage of public funds, in which the government asking for "help" to individuals in the management of public goods [26].

It's also to be highlighted, as in the past, that urban transformation investments aimed at improving physical, functional and environmental sustainability of the urban environment, have been a location advantage reflected in an increase of property value, but not within financial public administrations.

At this end, we propose a pluri-parametric model to assess how the level of conservation and maintenance of urban environment can influence property values.

The model proposed is test on a sample of data reflecting different context of the city of Naples.

In the next paragraph the model proposed will be presented and the results discussed in the conclusion.

\section{The Hedonic Model}

The model proposed is referred to a statistical model (Hedonic price method), based on pluriparametric algebraic functions - Generalized Additive Model - able to improve the "performances" of usual predictive pluriparametric model [25].

The algebraic structure of the model applied to the specific case under consideration is carried out on the real estate data samples and with the help of statistical tests and estimation evidence (the latter of empirical nature), by implementing the following semiparametric additive model based on an appropriate penalized spline function:

$$
\text { price }=\beta_{0}+\beta_{1} \text { flo }+\beta_{2} \text { elev }+\beta_{3} \text { manpro }+\beta_{4} \text { bath }+\beta_{5} \text { Lren }+\beta_{6} \text { manurb }+f_{1}(\text { area })+\varepsilon_{i}
$$

In this case, the dependent variable is represented by the bid price of the property, while the independent variables, representing the characteristics of the property selected, are: 
- Floor level (flo);

- Presence of elevator (elev), expressed by a dichotomic scale ( 1 if is present, 0 if not);

- Manteinance property condition (manpro), expressed by a dichotomic scale ( 1 if restored e 0 if not);

- Numbers of bathroom (bath);

- Level of renovation of urban environment (Lren), expressed by a dichotomist scale (1 if the property is located in a urban context recently renovated, 0 if not);

- Level of urban maintenance condition (manurb), expressed by a dichotomist scale 1-0 ${ }^{1}$;

- Commercial area expressed in square meters (area) and defined by a penalized spline function.

The homogeneous ${ }^{2}$ sample data, concern 62 units for residential real estate located in six areas of the city center of Naples and, more precisely, according to the classification in microzones implemented by the Land Registry in the following areas:

- Pianura;

- Traiano;

- Piave;

- Soccavo;

- Fuorigrotta;

- Materdei.

The urban areas examined have homogeneous building features, but different levels of conservation of urban public spaces. Every micro zone has been interested by the opening of a new underground station, but only in two cases (Fuorigrotta and Materdei) a renovation project of the urban environment has been also implemented. In all the other cases the condition of degradation of the urban context and the low level of conservation of public space are manifest. This difference of "urban quality condition", in context characterized by the same level of urban standard and accessibility, has allowed to appreciate significantly the variable "urban quality", expressed trough the two variables "level of renovation of urban environment "and "level of urban maintenance condition".

Particularly, in each micro zone not less that 10 properties have been selected, located within a distance of 500 meters from the underground station, considering not significant the influence of the urban quality conditions for building located at a major distance from such station.

The results show that no appreciable phenomena of multicollinearity subsist due to the low correlation between the explanatory variables.

The data, descriptive statistics of the sample and the main indices of model verification, are shown for completeness in the tables that follow.

Looking at the assessment point of view, the residue analysis shows no particular anomalies; from the statistical point of view, the index of determination is significant, equal to 0,945 (correct index equal to 0,939 ), as well as the test $F$ is significant at confidence level of $95 \%$.

The estimates of the fixed effects of the linear component of the model are summarized in Table 2.

Even if not all variables are statistically significant in the linear component, these are not excluded from the model, because appears to be significant on an economic point of view.

On the other hand, the non linear component of the model appears statistically significant, because no anomaly are observed in the values of the smoothing parameters (spar equal to 37,12) or in the degree of freedom ( $d f$ equal to 2,715).

The marginal price of each characteristic is reported in Table 3.

\footnotetext{
${ }^{1}$ The dichotomist scale is measured on a bases of a check list. The criteria used to measure the level of maintenance condition of public space are: level of condition of urban green, road surface, presence of waste, level of condition of pedestrian area, street lightning. An urban context is considered well preserved (1) if meet 3 of the above mention criteria, (0) if not.

${ }^{2}$ for typology and quality of buildings (residential units located in multi-storey buildings).
} 
Table 1. Experimental results

\begin{tabular}{|c|c|c|c|c|c|c|}
\hline Characteristic & Mean & Median & Min & Max & Std. Dev. & Data \\
\hline price & $€ 195.695$ & $€ 188.445$ & $€ 92.219$ & $€ 318.841$ & $€ 52.043$ & 62 \\
\hline area & 99,81 & 100 & 50 & 160 & 23,3 & 62 \\
\hline flo & 2,52 & 2 & 0 & 7 & 1,61 & 62 \\
\hline elev & & 0 & 0 & 1 & & 62 \\
\hline manpro & & 1 & 0 & 1 & & 62 \\
\hline bath & & 0 & 0 & 1 & & 62 \\
\hline Lren & & 0 & 0 & 1 & & 62 \\
\hline manurb & & 1 & 0 & 1 & & 62 \\
\hline
\end{tabular}

Table 2. Experimental results

\begin{tabular}{|c|c|c|c|c|}
\cline { 2 - 5 } \multicolumn{1}{c|}{} & coef & se & ratio & p-value \\
\hline intercept & -127.800 & 152.600 & $-0,8374$ & 0,4029 \\
\hline flo & 1.896 & 3.556 & 0,5332 & 0,5942 \\
\hline elev & 6.435 & 12.170 & 0,5288 & 0,5973 \\
\hline manpro & 9.686 & 11.520 & 0,8411 & 0,4008 \\
\hline bath & 19.520 & 12.480 & 1,5640 & 0,1186 \\
\hline Lren & 2.748 & 10.730 & 0,2561 & 0,7980 \\
\hline manurb & 11.840 & 10.040 & 1,1790 & 0,2390 \\
\hline
\end{tabular}

Table 3 Marginal prices

\begin{tabular}{|c|c|}
\hline \multicolumn{2}{|c|}{ Marginal prices } \\
\hline flo & 1.896 \\
\hline elev & 6.435 \\
\hline manpro & 9.686 \\
\hline bath & 19.520 \\
\hline Lren & 2.748 \\
\hline manurb & 11.840 \\
\hline
\end{tabular}

The marginal price of variable "area" range from $€ / \mathrm{sqm} 2.261,00$ approx. (for $60 \mathrm{sqm}$ ) to $€ / \mathrm{sqm}$ 1.831,00 approx. (for $160 \mathrm{sqm}$ ), these price is decreasing (according to the economic law of marginal utility) due to lower willingness to pay of traders increasing real estate consistency.

For brevity of discussion, the marginal prices for non-linear component of the model (variable "area") are given only graphically (figure 1), since the main objective to explain the variable "level of urban maintenance condition" only.

As is shown in the Table 3 the marginal price of the characteristic "level of urban maintenance condition" is 11.480 that represent the $6,05 \%$ of the average price of the data samples examined. While the presence of renovation project influence the average price for a percentage of $1,41 \%$.

The results obtained are in line with the international literature (cited in introduction) and allow to estimate a qualitative variable as the effect of urban quality on property value. 


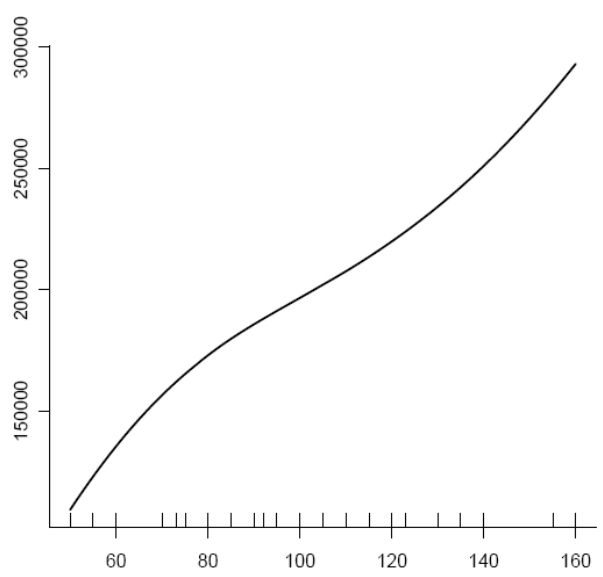

Figure 1 Marginal prices for non-linear component of model (variable "area")

\section{Conclusion and results}

The subject paper intends to estimate the impact that ordinary and extraordinary urban maintenance interventions can have on property values.

This issue appears of great relevance in the current environment where the lack of public funding causes certain Municipalities to explore creative solutions to fund the management and maintenance of public spaces involving the private while increasing at the same time the cadastral estimates and the real property taxes. The Hedonic Prices Model, based on a semiparametric addictive function has enabled to quantify an intangible variable concurring to the value creation of the property examined. The results obtained indicate that the maintenance and renovation conditions of the urban context affect the value of property for approximately $6 \%$; In other words one has a greater willingness to pay for such properties located in well kept urban contexts. Such willingness to pay is reflected on the higher cadastral income in those areas and therefore in higher property taxes.

The results obtained are consistent with existing literature and therefore support the methodology adapted.

\section{References}

[1] K. Lynch: Theory of a good city form, MIT Press (1984)

[2] L. D'Acci: Urban Quality of Life Estimates, Encyclopaedia of Quality of Life Research, Springer. (2012) ISBN 978-94-007-0752-8

[3] Quality of life in European Cities: facts and perceptions- OPEN DAYS 2007 Proceedings

[4] United Nations Human Settlements Programme: The Governing Council. Draft resolution on sustainable urban development through access to quality urban public spaces, (2011). Information on http:// www.unchs.org.

[5] H. Barton, G. Davis, R. Guise: Sustainable Settlements: a Guide for Planners, Designers and Developers. University of the West of England and The Local Government Management Board: Bristol (1995).

[6] L. Martincigh: Strumenti di intervento per la riqualificazione urbana. La complessità dell'ambiente stradale, Gangemi editore (2012)

[7] L. D’Acci: How Much Site Quality Influence Housing Value? (2014). SSRN: $\mathrm{http}: / /$ ssrn.com/abstract $=2374957$

[8] M. Lutzenhiser, and N. R. Netusil: The Effect of Open Spaces on a Home's Sales Price. Contemporary Economic Policy, 19, (2001) pp. 291-298 
[9] K. Tajima: New estimates of the demand for urban green space: implications for valuing the environmental benefits of Boston's big dig project. J. Urban Affairs 25, pp. 641-655 (2003)

[10] A. Morancho: A hedonic valuation of urban green areas. Landscape Urban Plan. 66, (2003) pp. 35-41

[11] A.Troy \& J. M. Grove: Property values, parks, and crime: A hedonic analysis in Baltimore, MD. Landscape and Urban Planning 87 (2008), pp. 233-245

[12] G. Acharya, LL. Bennett: Valuing open space and land-use patterns in urban watersheds. Journal of Real Estate Finance and Economics 22, (2001) pp. 221-37.

[13] D. Damigos and F. Anyfantis: The value of view through the eyes of real estate experts: $A$ Fuzzy Delphi Approach. Landscape and Urban Planning 101(2), (2011) pp. 171-178

[14] Wendy Y. Chen: Value of scenic views: Hedonic assessment of private housing in Hong Kong, Landscape and urban planning review, Volume 91, Issue 4, (2009), pp. 226-234

[15] G. Debrezion, E.A. Pels, P. Ritveld: The Impact of Railway Stations on Residential and Commercial Property Value: A Meta Analysis, Journal of Real Estate Finance and Economics 35, (2007), pp. 161-180

[16] R. Cervero \& C.D. Kang: Bus rapid transit impacts on land uses and land values in Seoul, Korea. Transport Policy, 18, (2011), pp. 102-116

[17] J. Luttik: The value of trees, water and open space as reflected by house prices in the Netherlands . Landscape and Urban Planning 48, (2000), pp. 161-167

[18] C.Y. Jim, Wendy Y. Chen: Impacts of urban environmental elements on residential housing prices in Guangzhou (China). Landscape and Urban Planning, 78, (2006). pp. 422-434

[19] J.C. Blanco, I. Flindell: Property prices in urban areas affected by road traffic noise. Applied Acoustics, vol. 72, (2011), pp. 133-141

[20] L. D'Acci: Grown, urban transformation, real estate value: Econometric cellular automata for the simulation of positional value. Lecture Notes in Computer Science, (2008), LNCS 5072.

[21] L. D'Acci: A mathematical aid for efficient distribution of social benefit in urban planning. In Rabino., G. \& Scarlatti, F. (Ed.). Advances in Models and Methods for Planning. Bologna: Pitagora (2009a)

[22] L. D’Acci: Spatial distribution of social benefit given by urban attractions. Lecture Notes in Computer Science LNCS 5592, (2009b), pp. 237-252

[23] V. Del Giudice, P. De Paola, F. Torrieri, Assetto urbanistico e valori immobiliari: il caso del Programma Integrato di Interventi nel quartiere di Pianure comune di Napoli, Proceedings of IF CRASC (2012)

[24] S. Rosen: Hedonic prices and implicit markets: product differentiation in pure competition. Journal of Political Economy 82 (1), (1974), pp. 34-55

[25] D. Ruppert, M.P. Wand, R.J. Carroll: Semiparametric regression, Cambridge University Press (2003)

[26] B. Manganelli: Maintenance, building depreciation and land rent, Applied Mechanics and Materials, Vol. 357-360 (2013), pp. 2207-2214 